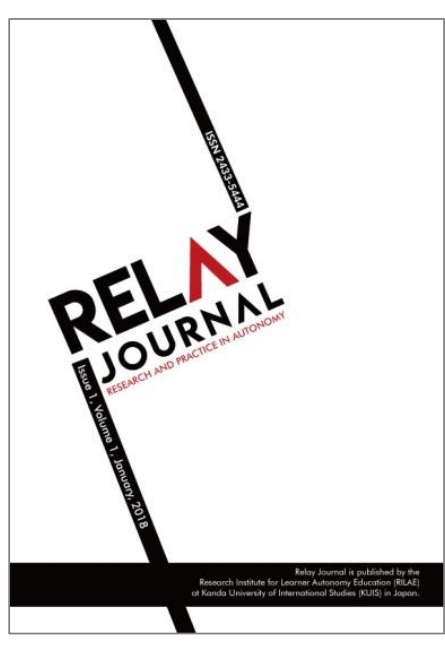

ISSN 2433-5444

\title{
Relay Journal
}

https://kuis.kandagaigo.ac.jp/relayjournal

\section{Reflecting on Approaches for Developing Learner Autonomy in a Juku and Eikaiwa Setting}

Ewen MacDonald, Kanda University of International Studies, Japan

\section{To cite this article}

MacDonald, E. (2018). Reflecting on approaches for developing learner autonomy in a juku and eikaiwa setting. Relay Journal, 1(1), 159-166.

\section{To link to this article}

https://kuis.kandagaigo.ac.jp/relayjournal/issues/jan18/macdonald/

This article may be used for research, teaching and private study purposes. Please contact the authors for permission to re-print elsewhere.

Scroll down for article. 


\title{
Reflecting on Approaches for Developing Learner Autonomy in a Juku and Eikaiwa Setting
}

Ewen MacDonald, Kanda University of International Studies, Japan

\begin{abstract}
A number of different approaches can be taken to provide students with greater control over their learning in order to develop learner autonomy. Teacher-based, classroom-based and curriculum-based approaches are similar in that their implementation causes changes to what are considered traditional educational norms. In this reflective article, these approaches are firstly summarised, and an overview of the author's teaching contexts is given. Then, the author, currently an MA TESOL program student and having recently undertaken a course on learner autonomy, reflects on using the approaches for promoting learner autonomy, in the context of his cram school (juku) and English conversation (eikaiwa) classes in Japan.
\end{abstract}

\section{Approaches for Promoting Autonomy}

A commonly accepted definition of learner autonomy is "the capacity to take control over one's own learning" (Benson, 2011, p.2). In summarising the major claims argued for promoting autonomy, Benson (2011) states that all learners have a propensity to take control of their learning, those who lack control have the ability to develop it, and growth in autonomy leads to better language learning. Benson (2011) classifies various approaches to facilitate autonomy, three of which "focus on changes to conventional educational structures" and provide students with the opportunity "to make decisions about their learning within collaborative and supportive environments" (p. 163).

Firstly, teacher-based approaches highlight the role of teachers and teacher education in fostering autonomy, based on the premise that teachers themselves must show a level of autonomy in their approaches to teaching and learning to successfully promote the development of autonomy (Benson, 2011).

Secondly, classroom-based approaches involve giving learners control over classroom decisions through planning and evaluating their learning. Previous studies have shown the 
effectiveness of involving learners in such planning for developing autonomy and motivation, as well as the advantages for students with different learning styles and preferences (Benson, 2011). In addition, Oscarson (as cited in Benson, 2011) identifies several benefits for students in self-assessing their learning, including raising awareness of learning processes and the possible goals of language learning, putting learners in a better position to take control of their learning.

Finally, curriculum-based approaches take the concept of learner control and extend this to the overall curriculum, through learners making decisions over learning content and procedures together with their teacher (Benson, 2011).

\section{Juku and Eikaiwa}

Before reflecting on using these approaches to promote learner autonomy, it is important here to briefly describe the educational settings that I work in, and their place within the educational system in Japan.

$J u k u$ (private cram schools) are a part of the influential private market for English language education in Japan (Lowe, 2015). They provide supplementary education to students on a range of subjects including English, primarily in order to prepare and support them for taking university entrance examinations (Lowe, 2015). During their education, approximately $70 \%$ of Japanese students attend juku at some stage (Bray, 2007), with the percentage gradually rising as they progress from elementary school to high school (Bray \& Lykins, 2012). My students range from 6th-grade at elementary school to 3rd-grade at high school, and are between 11 and 18 years of age.

Eikaiwa, the study of English conversation, occurs in Japan in a range of settings, including at large, profitable eikaiwa chain schools, private businesses, small community groups and non-profit organisations (Kubota, 2011). Students are often adults who may attend for instrumental purposes or as a leisure activity, but may also be secondary school students or younger children (Kubota, 2011). In my case, I teach eikaiwa classes at the juku itself to adults. 


\section{Teacher-Based Approaches}

As a teacher, I see myself in the role of 'teacher as facilitator' who provides support for learning. In developing learner autonomy, Boud (as cited in Voller, 1997) summarises the type of support that a teacher gives. This includes assisting learners in planning and undertaking independent language learning, helping them to self-evaluate their learning, and assisting learners in gaining the ability and knowledge to do these things.

To support autonomous learning, I aim to create a student-centred classroom environment by taking a task-based language teaching approach where possible, encouraging active participation and sharing of ideas among students, and using activities that provide opportunities for student interaction and collaboration. For example, in my juku classes, I often use information gap tasks, dictation activities between students, sentence matching and ordering in pairs, small group discussions, and get students to work together as a group to brainstorm ideas. In addition, I endeavour to raise students' awareness of effective learning strategies in order to help them be ready to learn when they arrive at class, to learn most effectively during the limited classroom time, and continue to learn independently beyond the classroom door.

As a facilitator, I also keep my lesson plans flexible so I can respond to student questions and unpredicted occurrences that create opportunities for learning. Learners in my eikaiwa classes in particular have many questions, and while responding to these takes time, I want to let my learners drive the classroom as much as possible to give them more control.

Among the attempts made at identifying dimensions of teacher autonomy, Smith (2003) summarises suggestions made by various authors to conclude that in order to successfully promote learner autonomy, teachers should have both the capacity, and freedom from control, to self-direct their own teaching.

Little (as cited in Smith, 2003) advocates that the capacity for self-directed teaching involves the application to teaching of "reflective and self-managing processes" (p. 5). To self-direct my teaching, I regularly engage in reflective practice through critical reflection of my teaching and my roles as a teacher. In addition, I engage in reflective dialogue with my teaching colleagues and peers on my MA TESOL program. Both self-reflection and reflective dialogue allow me to make more informed decisions in the classroom. I have also undertaken action research and intend to continue this, especially through learning about student 
perspectives, in order to better understand the effects of my classroom practices and make changes that benefit student learning and autonomy.

In terms of freedom for self-directed teaching, Benson (2011) states that "most teachers work under conditions in which the control that they exercise is severely constrained" (p. 189). I am relatively free from constraints for my eikaiwa classes, and am able to provide more power to my students over the lesson and curriculum content. However, as a teacher in a juku, factors such as educational policy, curriculum, parental expectations and students' reasons for attending the $j u k u$ limit my autonomy as a teacher to develop learner autonomy. Lessons are often grammar-focused and are centred around reading passages from past entrance examinations that I am required to spend time on, such as assisting with reading comprehension or going through the accompanying questions. While I am not explicitly aware of my students' reasons for attending juku, O’Donnell (2003) found that students typically attend either to prepare for entrance examinations, improve their English ability, or both. I am aware that many of my students' parents send their children to the juku for these same reasons, but in particular to help them succeed in entrance examinations. This can be attributed to the importance placed on entrance examinations and the competitiveness of entering into highly regarded schools in Japan. In a survey conducted in 2008 on why parents believe juku attendance is "heating up", nearly $60 \%$ of parents believed this was due to a society where emphasis is placed on academic credentials (Bray \& Lykins, 2012).

When faced with limitations, Benson (2011) notes that the teacher's role is to identify how constraints on learning can be "mediated through their agency" (p. 189). Therefore, through continuous reflection, I look to identify spaces within these constraints in which I can provide students with greater control over their own learning, some of which are mentioned in the next section.

\section{Classroom-Based Approaches}

I hold the view that if learners have an element of control over their own learning through being involved in the decision making process, it not only helps them to take more responsibility over their learning, but can also greatly increase motivation, hence having a positive effect on the affective factors that strongly influence language learning and autonomy. When reflecting on my history as an L2 learner, I realise that the opportunities that I had to influence my own learning were a powerful motivator for me to learn. 
Among the constraints of teaching in a juku, homework is an aspect that I have some control over. I had previously found through a small action research project that the majority of my students have positive perceptions about their homework (MacDonald, 2017a, 2017b). However, suggestions made by some students led me to conduct further research and ask follow-up questions. Most students again expressed satisfaction with existing homework, particularly writing short compositions, feeling it is useful preparation for entrance examinations. However, several students expressed that they wanted more practice writing sentences based on words learnt from the reading passages used in class. In addition, some students wanted to select and read books, believing it would be fun and also useful for acquiring English expressions. These responses give me an opportunity to increase learner control in the future by giving students greater choice for homework, such as letting them decide whether they want to write a composition and/or make sentences using target words, or even offering extensive reading for interested students (and parents).

In class, I have begun to give students the choice over the vocabulary they practice, based on what they feel is most useful to them. Most students tend to choose at least some words that other students do not, and in one particular lesson, I noticed that a student who wishes to enter a science university chose relatively scientific vocabulary to focus on, in contrast to his classmates. I believe I can extend this into activities that promote autonomy, such as getting students to independently look up and practice using new words before teaching them to their classmates, or by getting students to work together to practice forming example sentences.

For my eikaiwa lessons, my students had previously remarked that they enjoy having free conversation and would like more opportunities to do this. Therefore, I often begin my lessons by asking a question that stimulates open conversation, such as by asking what everyone did on the weekend. I realise now that I can get my learners more involved with this. A practical and straightforward method would be to get learners themselves to brainstorm the topics that they would like to discuss, for example current events, or happenings in learners' lives. Different learners could be given responsibility on a weekly basis for selecting a topic and starting the conversation with the class.

Looking forward, I would like to increase learner control and responsibility through continued self-assessment, in order to make students more aware of their learning and give them a greater sense of achievement and progress. At present, whenever possible I get my 
juku and eikaiwa students to engage in reflection at the end of each class by saying or writing down one or two things that they learnt from the lesson. I could deepen this self-evaluation by getting my students to keep a record of what they have learnt through using log sheets or a learning diary. For my eikaiwa students especially, I can get them to evaluate their learning and achievement through self-assessment tools such as can-do statements or self-rating scales. I can also build more reflective questions into my lessons as well as vary the questions I ask. For example, at the end of lessons and even after activities, I can ask students how they found the lesson/activity, what they believed they did or did not do well, and what they found difficult. Another possibility is instead of letting students know the lesson objectives at the beginning of class every time, at the end of the lesson I could get students to reflect on what they believed the lesson objectives to be.

\section{Curriculum-Based Approaches}

Most of my adult eikaiwa learners have similar purposes or goals for taking English lessons: to be able to communicate in English when travelling abroad, or communicating with foreigners in Japan such as when volunteering at events. I began using set textbooks with my classes, but I soon realised that not all chapters were helpful in meeting my learners' goals and purposes for learning English, and I found myself skipping over pages and

supplementing with my own materials. Therefore, I asked my students to consider the kind of situations and possible scenarios that they may encounter that they wanted to learn and practice using English for. I have since used their preferred learning content to help guide my ongoing curriculum through the selection and creation of materials, while attempting to cover what they wish to learn and practice as much as possible. My students have responded positively to this, expressing that they find the lesson content to be helpful. I believe the choice over learning to be very motivating for them, and I will continue to revisit what they want to learn.

While I previously asked students anonymously when negotiating the curriculum, I feel that if I did this again, the process of co-constructing the curriculum does not have to be anonymous, especially in classes where there is a positive group dynamic and when most learners share similar aims for learning. When I first asked my learners, some of them had very clear and specific ideas on scenarios and the kinds of English they wanted to learn, while others had either never thought about it, or only had broad ideas. They needed time to 
reflect to consider what they would like to do, as I assume they were used to teachers making decisions for them. Negotiating the curriculum together with students through a joint discussion could help all students to reflect more deeply on what they want to learn and why.

\section{Conclusion}

While the concept of autonomous learning has always influenced my teaching practices, undertaking an MA TESOL program including a learner autonomy course has deepened my knowledge of the dimensions of autonomy that learners can develop. I have become more aware of a variety of methods for promoting autonomy, including teacher, classroom and curriculum based approaches, which provide opportunities for students to make decisions about their learning. I contend that autonomy is one of the most important goals of language learning because of its strong connection with the cognitive, affective and social factors of learning, and I will continue striving to promote it in my teaching practice, to make students better language learners who can take control over their own learning.

\section{Notes on the contributor}

Ewen MacDonald is a student in the MA TESOL Program at Kanda University of International Studies. He currently teaches in an English program at a cram school in Japan, as well as teaching English conversation classes to adults. His research interests include teacher cognition, learner autonomy, corrective feedback, and vocabulary.

\section{References}

Benson, P. (2011). Teaching and researching autonomy (2nd ed.). Harlow, UK: Pearson. Bray, M. (2007). The shadow education system: Private tutoring and its implications for planners (2nd ed.). Paris, France: UNESCO International Institute for Educational Planning. Retrieved from http://unesdoc.unesco.org/images/0011/001184/118486e.pdf

Bray, M., \& Lykins, C. (2012). Shadow education: Private supplementary tutoring and its implications for policy makers in Asia. Manila, Philippines: Asian Development Bank. Retrieved from https://www.adb.org/sites/default/files/publication/29777/shadow- 
education.pdf

Kubota, R. (2011). Learning a foreign language as leisure and consumption: Enjoyment, desire, and the business of eikaiwa. International Journal of Bilingual Education and Bilingualism, 14(4), 473-488.

Lowe, R. J. (2015). Cram schools in Japan: The need for research. The Language Teacher, 39(1), 26-31. Retrieved from http://jalt-publications.org/files/pdf$\underline{\text { article/39.1tlt_art5.pdf }}$

MacDonald, E. (2017a). Ask your students: Japanese students' feelings and beliefs on homework in juku. Explorations in Teacher Development, 24(2), 13-21.

MacDonald, E. (2017b, September). Reflecting on teaching practice through learning students' perceptions on homework. TEIS News. Retrieved from http://newsmanager.commpartners.com/tesolteis/issues/2017-09-25/3.html

O’Donnell, K. (2003). Uncovering first year students' language learning experiences, attitudes, and motivations in a context of change at the tertiary level of education. JALT Journal, 25(1), 31-62. Retrieved from http://www.jaltpublications.org/archive/jj/2003a/art2.pdf

Smith, R. C. (2003). Teacher education for teacher-learner autonomy. In J. Gollin, G. Ferguson \& H. Trappes-Lomax (Eds.), Symposium for language teacher educators: Papers from three IALS symposia [CD-ROM]. Edinburgh, Scotland: IALS, University of Edinburgh. Retrieved from http://homepages.warwick.ac.uk/ elsdr/Teacher_autonomy.pdf

Voller, P. (1997). Does the teacher have a role in autonomous language learning? In P. Benson \& P. Voller (Eds.), Autonomy and independence in language learning (pp. 98-113). Harlow, UK: Addison Wesley Longman Limited. 